\title{
Academic Achievement Motivation and Attitude of Senior Secondary School Students towards Examination Malpractice in Uyo Metropolis, Akwa Ibom State, Nigeria
}

\author{
Cornelius C. Okoro, $\mathrm{PhD}$ and Nsisong A. Udoh, M.Ed. \\ Department of Educational Foundations, Guidance and CounsellingUniversity of Uyo, UyoP.M.B. 1017, Akwa \\ Ibom State, Nigeria
}

\begin{abstract}
The study aimed at finding out whether academic achievement motivation influenced the attitude of senior secondary two students towards examination malpractice. Three research questions and three hypotheses were formulated to direct the conduct of the study. The sample for the study comprised 350 students of both sexes drawn by means of the multistage random sampling technique.A researcher-made instrument entitled Attitude Towards Cheating in ExaminationQuestionnaire (ATCEQ) was used in collecting data on students' attitude towards examination malpractice while the Aberdeen Academic Motivation Inventory (ACMI) was used in assessing academic achievement motivation.Theresults showed no significant difference between the academic achievement motivation as well as the attitude towards examination malpractice of male and those of female students. It was also found that students' academic achievement motivation influenced their attitude towards examination malpractice. These results were discussed and suggestions were proffered for educational practice.
\end{abstract}

Keywords:Examination malpractice; Attitude; Motivation; Academic achievement; Educational psychology; School counselling

\section{Introduction}

Examination malpractice is currently a very serious problem in the Nigerian education system. Okoro (2001a:112) described it as "a virus that has been eating up the fabrics of the Nigerian education system", exerting "a strong negative influence on the functionality of education in the country." He quoted Denga and Denga (1998) as claiming that examination malpractice was capable of ruining the educational system and also impairing the efficacy of the nation's labour force.In the same vein, several researchers also observed that examination malpractice is very rampant in Nigeria. The prevalence of this vice across all the levels of the nation's education system has variously been reported by Tukurand Musa (2001), Ugodulunwa(2001), Ogbonna (2001), and Okorodudu(2010)to have attained an alarming proportion with Udoh (2011) describing it as a "national emergency situation".

Examination malpractice as well as other forms of academic cheating has not been problems peculiar to the Nigerian education system alone. In fact, academic dishonesty as a whole has been reported in literature as constituting an issue of great global concern that researchers in both developed and developing countries have tirelessly proffered suggestions on how to combat it. According to Zhou and Lan (2007), many recent studies had reported that academic dishonesty became a distressing concern across university campuses in the United States. According to them, it had further been reported that in Asian countries, especially in China, where the definition of academic dishonesty were "looser" than in the US, academic dishonesty was running out of control.

Bjorklund and Wenestam (1999) on their part also referred to cheating or academic misconduct as a well-known problem in many European countries, as well as in the United States of America. Rabi, Patton, Fjortoft and Zgarrick (2006) cited a US News and World Report cover story as indicating that at every academic level, from high school to graduate school, students cheat; and most of the students believe that they need to cheat in order to succeed in today's world. According to Whitley, Nelson and Jones (1999), academic dishonesty is a major problem in American colleges and universities. Al-Qaisy (2008) of Tafila Technical University, Jordan claimed that academic cheating was a widespread problem in higher education. Several other research studies also pointed to the high prevalence of academic cheating both in the America and the world at large. (Alschuler\&Blimling, 1995; Anderson \&Obenshain, 1994; Burnett, Rudolph \& Clifford, 1998; Cole \& Kiss, 2001; Davis \&Ludvigson, 1995; Diekhoff, et al, 1996; Green \& Saxe, 1992; Jordan, 2001).The magnitude of the problem of academic cheating is also manifested in the bulk of research works associated with it and the fact that literature is filled with a myriad of suggestions on how the ugly phenomenon can be tackled.

Concerning the prevalence of examination malpractice in Nigeria, many associated negative effects have been reported by authors. Some authors claimed that it has constituted a serious threat to educational 
standards and to national development efforts (Maduabum, 2001; Jacob \&Lar, 2001; Mangvwat, 2001; Ogbonna, 2001; Okorodudu, 2010). Furthermore, examination malpractice was found to discourage hard work upon which the survival of the individual and that of the society are based (Okoro,2001 a).Jacob and Lar (2001) also pointed out that examination malpractice makes the student to lose the ability to work hard in his studies. This is so due to the fact that it is not the individual who worked hard that obtained the best results under a system where examination malpractice prevailed.

There is no doubt that there exists a relationship between attitude towards examination malpractice and actual involvement by students in examination malpractice. Although many psychologists disputed the direct influence of attitude on behaviour, they, however, opined that attitudes were useful in the sense that they gave people a simplified and practical guide for appropriate behaviour (Johnson, 1979). Feldman (2000) was of the view that whereas attitude sometimes influenced our behaviour, our behaviour on its part sometimes shaped our attitude.Amoo (2002) opined that when an attitude is favourable or positive, it enhances active performance that leads to success. On the other hand, when it is unfavourable or negative, it is often reflected by an individual's lack of interest and non-participation in an activity.

Amoo and Rahman (2004) also claimed that the relationship between attitudes and performance is a consequence of a reciprocal influence, in the sense that attitudes affect achievement and achievement in turn affects attitude. According to Johnson (1979), some attitudes helped students to function effectively in school while some others interfered with school life. Also, Udokang and Okoro (2004) intimated that the attitudes possessed by children affect their school work as well as their learning. In the opinion of Blair, Jones and Simpson (1975), a child with positive attitude about his teacher, who also likes school work, will inevitably experience some success. Johnson (1979) intimated that some attitudes, like positive self-esteem, help students to function effectively in school, and that on the contrary, those that are negative in nature, like fear of failure, interfere with schoolwork. Possessing a positive attitude towards examination malpractice will most probably interfere with an individual's schoolwork. Since people's engagement in examination malpractice interferes with those individual's schoolwork, possession of a positive attitude towards examination malpractice will most probably have a similar effect on the individuals. These go further to indicate that there is a link between attitude towards examination malpractice and the actual involvement in it by students.

It is evident from this discussion that one's favourable attitude towards examination malpractice is related to the possibility of one's actual participation in examination malpractice. Actual involvement in examination malpractice has numerous negative consequences for the individual, including inhibiting his learning and academic performance. Research has shown that there is a positive relationship between motivation and achievement (Egbezor, 1986) as well as between academic achievement motivation and performance (Okoro, 2001b). Furthermore, unlike their counterparts who lack it, individuals with high achievement motivation have been observed to think that success is caused by a combination of their efforts and ability and that failure is caused by lack of effort; and they thereby strive to do well (Johnson, 1979).

Gottfried (1990) found academic intrinsic motivation to be positively related to achievement, among other factors. It is not, however, clear whether there is any relationship betweenone's academic motivation and one's attitude towards examination malpractice. Furthermore, no study has been found to examine this relationship. A clue to the nature of such a relationship was given by Adebayo (2010). On the basis of his findings, in a study that investigated the relationship between achievement motivation and academic cheating behaviour, Adebayo concluded that students who were high on achievement motivation were less likely to cheat in their academic work. Furthermore, those low in achievement motivation were more likely to cheat in their academic work. This was because academic achievement motivation and its components were found to relate in a negative direction with cheating behaviour index. In the same vein, Centra (1970) found, among others, that those with lenient attitudes towards academic cheating tended to be less academically motivated. On the basis of findings of previous research, Newstead, Franklyn-Stokes and Armstead (1996) had, on the contrary, speculated that individuals high in achievement motivation would more likely have higher propensity to cheat than those low in achievement motivation.

Since there was no clear-cut understanding of the nature of the relationship between the phenomena under study, the researchers were motivated to embark on this study. The purpose of this study, therefore, was to examine the influence of students' academic achievement motivation on their attitude towards examination malpractice and the implications it may hold for education.

\subsection{Research Questions}

The following research questions were generated to guide the conduct of the study:

(1) How does gender influence the academic achievement motivation of senior secondary school students in Uyo metropolis?

(2) How does gender influence the attitude of senior secondary school students towards examination malpractice in Uyo metropolis? 
(3) The academic achievement motivation of senior secondary school students in Uyo metropolis does not significantly influence their attitude towards examination malpractice?

\subsection{Hypotheses}

The research questions were converted into the following null hypotheses for the purpose of statistical testing and analyses:

$\mathrm{H}_{\mathrm{o}}$ 1. There is no significant difference between the academic achievement motivation of male and that of female senior secondary school students in Uyo metropolis

$\mathrm{H}_{\mathrm{o}} 2$. There is no significant difference between the attitude of male and that of female senior secondary school students in Uyo metropolis towards examination malpractice.

$\mathrm{H}_{\mathrm{o}} 3$. Senior secondary school students' academic achievement motivation does not significantly influence their attitude towards examination malpractice in Uyo metropolis.

\subsection{Area of Study}

\section{Research Method}

The study was conducted in Uyo metropolis. Uyo is the capital city of Akwa Ibom State. Akwa Ibom State - one of Nigeria's thirty six States - is located in the south-south geopolitical zone of Nigeria.

\subsection{Research Design}

The design used for the study was the ex post facto survey design. This design was adopted in view of the fact that the research was intended to examine the already seemingly existing influence of academic achievement motivation on students' attitude towards examination malpractice- - a phenomenon over which the researchers had no control.

\subsection{Population for the Study}

The population comprised all the Senior Secondary Two (SS II) students in all the government owned secondary schools situated in Uyo metropolis.

\subsection{Sample and Sampling Technique}

The sample for the study consisted of 350 male and female students drawn by means of the multistage random sampling technique. At first, five mixed schools were randomly drawn from the 16 government owned schools in study area. Then, 35 male and 35 female SS II students were drawn from each of the five schools. This gave a total sample of 350 SS II students for the study.

\subsection{Instruments for Data Collection}

Two instruments were utilised by the researchers in data collection. The instruments were:

1. Attitude Toward Cheating in Examination Questionnaire (ATCEQ). This instrument contained 10 items developed by the researchers to elicit responses that will determine the extentto which the attitude of a student towards cheating in examination was positive or negative.

2. The Aberdeen Academic Motivation Inventory (ACMI). This was used to measure students' academic achievement motivation. This instrument designed and validated by Entwistle (1976) consisted of twenty-four items to each of which the students were instructed to give a "Yes" or "No" response. Their responses were checked with the correct responses in order to determine the academic motivation score for each of the students.

\subsection{Research Procedure}

The researchers administered copies of both instruments as a pair on the respondents in their respective schools and allowed sufficient time for them to be completed. Afterwards, the completed copies of the research instruments were retrieved for scoring, collation and analysis using the Statistical Package for Social Sciences (SPSS).

\subsection{Method of Data Analysis}

The data obtained from the field survey were entered into the SPSS computer program for analysis. The first and second hypotheses were tested using student $t$-test at $95 \%$ confidence interval while the third hypothesis was tested using One-way Analysis of Variance (ANOVA). Since the F-value of the ANOVA was significant, a further analysis was done on the third hypothesis using Fisher's Least Significant Difference post hoc testin order to ascertain the contributions of the various groups to the significance of the f-value. Details of the data analyses and results obtained are presented in the following section. 


\section{Results}

The results of data analyses done on the research variables are here presented in the light of the hypotheses tested in the study.

$\mathrm{H}_{\mathrm{o}}$ 1. There is no significant difference between the academic achievement motivation of male and that of female senior secondary school students in Uyo metropolis

Table 1: t-test analysis of the difference between male and female students' academic achievement motivation

\begin{tabular}{|c|c|c|c|c|c|c|c|}
\hline & Student gender & $\mathrm{n}$ & $\bar{\chi}$ & Std. Deviation & t-calc. & Df & t-critical \\
\hline \multirow{2}{*}{$\begin{array}{l}\text { Students' academic achievement } \\
\text { motivation }\end{array}$} & Male & 175 & 18.69 & 2.382 & \multirow[t]{2}{*}{1.67} & \multirow[t]{2}{*}{348} & \multirow[t]{2}{*}{1.97} \\
\hline & Female & 175 & 19.09 & 2.025 & & & \\
\hline
\end{tabular}

$\mathrm{p}<.05$

The analysis in Table 1 shows that the calculated value of the t-statistic (1.67) is less than the critical value of the t-test (1.97) at 95\% confidence interval and 348 degrees of freedom. Based on the decision rule $(\mathrm{p}<.05)$, the hypothesised null difference between male and female senior secondary school students' academic achievement motivation in Uyo metropolis was upheld.

$\mathrm{H}_{\mathrm{o}}$ 2. There is no significant difference between the attitude of male and that of female senior secondary school students in Uyo metropolis towards examination malpractice.

Table 2: t-test analysis of the difference between male and female students' attitudes toward examination malpractice

\begin{tabular}{llccccc}
\hline & Student gender & $\mathrm{n}$ & $\bar{\chi}$ & Std. Deviation & t-calc. & Df \\
\hline Students' attitudes toward & Male & 175 & 25.14 & 6.780 & 0.89 & 348 \\
examination malpractice & Female & 175 & 25.73 & 5.329 & 1.97 & \\
\hline
\end{tabular}

$\mathrm{p}<.05$

The analysis in Table 2 shows that, as hypothesised, there is no significant difference between the attitude of male and that of female senior secondary school students in Uyo metropolis towards examination malpractice. This decision was reached using the decision rule: $\mathrm{p}<.05$ ( $\mathrm{t}$-calculated 0.87 ; $\mathrm{t}$-critical $=1.97)$.

$\mathrm{H}_{\mathrm{o}}$ 3. The academic achievement motivation of senior secondary school students in Uyo metropolis does not significantly influence their attitude towards examination malpractice.

Table 3: ANOVA of the influence of students' academic achievement motivation on their attitude towards examination malpractice

\begin{tabular}{|c|c|c|c|c|c|}
\hline Source of Variation & SS & $\mathrm{df}$ & MS & $\mathrm{F}$ & F-critical \\
\hline Between Groups & 745.318 & 2 & 372.66 & 10.58 & $3.02 *$ \\
\hline Within Groups & 12222.671 & 347 & 35.22 & & \\
\hline Total & 12967.989 & 349 & & & \\
\hline
\end{tabular}

It would be observed in Table 3 that the calculated F-value of 10.58 is greater than the critical value of the F-statistics (3.02) at .05 level of significance. Based on the decision rule $(\mathrm{p}<.05)$, the null hypothesis which supposed that senior secondary school students' academic achievement motivation does not significantly influence their attitude towards examination malpractice in Uyo metropolis was rejected. This result shows that the academic achievement motivation of senior secondary school students in Uyo metropolis does significantly influence the attitude of these students towards examination malpractice. To examine the details of this result, a post hoc test for least significant difference was conducted as shown in Table 4.

Table 4: Fisher's least significant difference post hoc tests for Hypothesis 3

\begin{tabular}{|c|c|c|c|c|c|c|}
\hline \multicolumn{7}{|c|}{ Multiple Comparisons } \\
\hline \multicolumn{7}{|c|}{$\begin{array}{l}\text { Dependent Variable: Students' Attitude to Examination Malpractice } \\
\text { LSD }\end{array}$} \\
\hline \multirow{2}{*}{$\begin{array}{l}\text { (I) Academic } \\
\text { Achievement } \\
\text { Motivation }\end{array}$} & \multirow{2}{*}{$\begin{array}{l}(\mathrm{J}) \text { Academic Achievement } \\
\text { Motivation }\end{array}$} & \multirow{2}{*}{$\begin{array}{l}\text { Mean Difference } \\
(\mathrm{I}-\mathrm{J})\end{array}$} & \multirow[t]{2}{*}{ Std. Error } & \multirow[t]{2}{*}{ Sig. } & \multicolumn{2}{|c|}{$95 \%$ Confidence Interval } \\
\hline & & & & & Lower Bound & Upper Bound \\
\hline \multirow[b]{2}{*}{1} & 2 & $-2.327^{*}$ & .664 & .001 & -3.63 & -1.02 \\
\hline & 3 & $-4.759^{*}$ & 1.224 & .000 & -7.17 & -2.35 \\
\hline \multirow{2}{*}{2} & 1 & $2.327^{*}$ & .664 & .001 & 1.02 & 3.63 \\
\hline & 3 & $-2.433^{*}$ & 1.208 & .045 & -4.81 & -.06 \\
\hline
\end{tabular}


Academic Achievement Motivation and Students' Attitude towards Examination Malpractice

\begin{tabular}{rrrrrrr}
\hline 3 & 1 & $4.759^{*}$ & 1.224 & .000 & 2.35 & \\
& 2 & $2.433^{*}$ & 1.208 & .045 & .17 \\
\hline
\end{tabular}

*. The mean difference is significant at the 0.05 level.

To understand the result presented in Table 4 and furnish more meaning to the interaction of the variables under investigation, students' academic achievement motivation was examined at three scaled levels: (1) Above average motivation (2) Average Motivation and (3) Below Average Motivation. The least significant difference was observed between 1 and 2 (Above average motivation and Average motivation); suggesting that students with these levels of academic achievement motivation showed closely identical positive attitudes toward examination malpractice. A careful study of the data in Table 4 in general shows a consistency in the differences in the attitudes of senior secondary school students towards examination malpractice based on their levels of academic achievement motivation. Noteworthy is the finding that all the differences were significant and demonstrate a continuum of dissimilarity: students who recorded above average academic achievement motivation also recording more positive attitudes towards examination malpractice than students who recorded below average academic achievement motivation. Thus, the data in Table 4 shows clearly that the academic achievement motivation of senior secondary school students in Uyo metropolis does significantly influence the attitude of these students towards examination malpractice.

\section{Discussion of Results}

The result in Table 1 shows that there is no significant difference between the academic achievement motivation of male and that of female senior secondary school students in Uyo metropolis. This implies that both male and female students in senior secondary schools in the study area are on a level playing ground in terms of their academic achievement motivation. Neither are males significantly more motivated than females nor are females significantly more motivated than males. This finding provides for gender studies which may seek to ascertain whether there exists gender bias in students' academic achievement motivation. Furthermore, it validates the rationale for examining together the influence of male and female students' academic achievement motivation on their attitude towards examination malpractice.

The result in Table 2 shows that there is no significant difference between the attitude of male and that of female senior secondary school students in Uyo metropolis towards examination malpractice. This implies that both male and female students in senior secondary schools in Uyo metropolis share identical attitudes towards examination malpractice. The attitude of male students is neither significantly more positive nor significantly more negative than the attitude of female students towards examination malpractice. This result provides for gender studies which may seek to ascertain whether there exists gender bias in students' attitude towards examination malpractice in the study population. Moreover, it also provides data for gender studies which may tend to ascribe greater or lesser criminality to males or females in similar school examination contexts in keeping with contemporary trends in delinquency studies and discourses. Most importantly, this result validates the decision of the current study to examine together the attitude of male and female students towards examination malpractice in Uyo metropolis.

The results in Table 3 and Table 4 show that the academic achievement motivation of senior secondary school students in Uyo metropolis significantly influences the attitude of the students towards examination malpractice. These results are in line with the researchers' expectation that one's academic achievement motivation should influence one's attitude towards examination malpractice. This is finding is corroborated by such authors as Egbezor (1986), Gottfried (1990) and Okoro (2001b) who indicated from their various studies that students' academic achievement motivation relates with as well as influences students' performance. Furthermore, Johnson (1979), Feldman (2000) and Amoo and Rahman (2004) variously reported that performance and attitude have reciprocal influences on each other. This further supports the outcome of this study presented in Table 3 and Table 4.

\section{Conclusion and Recommendations}

In the light of the findings of the study, the researchers conclude that:

1. There is no difference between the academic achievement motivation of male and female senior secondary school students.

2. There is no difference between the attitude of male and that of female senior secondary school students towards examination malpractice.

3. Senior secondary school students' academic achievement motivation influences their attitude towards examination malpractice.

In view of the foregone conclusions, the researchers recommend that the fight against examination malpractice and every form of academic dishonesty should be more proactive. Instead of waiting for the academic crimes to be committed, especially on the part of the students, in order to punish the culprits-who may never be caught, as often observed - the following would be more effective remedies: 
1. Educational Psychologists and School Guidance Counsellors should be employed and adequate numbers of them should be deployed to all secondary schools - all educational institutions.

2. Educational Psychologists and School Guidance Counsellors working in schools should develop and implement various programmes of behaviour modification and attitudinal reorientation. These programmes should focus on inculcating positive attitudes towards academic dishonesty; such positive attitudes will enable students abhor examination malpractice and every form of academic dishonesty.

3. Educational Psychologists in educational institutions should collaborate with School Guidance Counsellors as a psychoacademic team and help students build and maintain their academic achievement motivation. It has been established by this study that high levels of academic achievement motivation contributes to examination honesty as these students are internally motivated to excel in their academics.

4. The government should give priority to making educational resources available for teaching and learning. It is the opinion of the researchers that when educational resources are available and accessible, teaching will the effective and learning will be less laborious. Such a learning environment is less likely to breed fraudulent examination tendencies among students and staff of educational institutions.

\section{References}

[1]. Adebayo, S. O. (2010). Correlation between academic cheating behaviour and achievement motivation.Nature and Science, 8(12), 130 - 134. Retrieved on $20^{\text {th }}$ September, 2012 from http://www.sciencepub.net

[2]. Al-Qaisy, L.M.(2008). Students' attitudes toward cheating and relation to demographic factors.European Journal of Social Sciences, $7(1), 140-146$.

[3]. Alschuler, A. S.,\&Blimling, G. S. (1995) Curbing epidemic cheating through systemic change. College Teaching, 43(4), $123-126$.

[4]. Amoo, S. A. (2002). Analysis of problems encountered in teaching and learning of mathematics in secondary schools. ABACUS:The Journal of the Mathematical Association of Nigeria, 27(1), 130-135.

[5]. Amoo, S. A., \&Rahman, M. A. (2004). Secondary school students' attitudes to learning mathematics in the world of Information Technology: Implications for mathematics teachers and teacher preparation. In M. A. G. Akale (ed.). Proceedings of the STAN $45^{\text {th }}$ Annual Conference held at Abuja $19^{\text {th }}-23^{\text {rd }}$ August, pp.179-182.

[6]. Anderson, R. E.,\&Obenshain, S. S. (1994). Cheating by students: findings, reflections, and remedies. Academic Medicine, 69(5),323-332.

[7]. Bjorklund, M., \&Wenestam, C. (1999). Academic cheating: frequency, methods and causes, Proceedings of the 1999 European Conference on Educational Research. Lahti, Finland. Available at: www.leeds.ac.uk/educol/documents/00001364.htm

[8]. Blair, G. M., Jones, R. S., \& Simpson, R. H. (1975).Educational psychology ( $4^{\text {th }}$ ed.). New York: Macmillan Publishing Co., Inc.

[9]. Burnett, D. D., Rudolph, L., \& Clifford, K. O. (Eds.). (1998). Academic Integrity Matters.Monograph 20. Washington, D. C.: National Association of Student Personnel Administrators.

[10]. Centra, J. A. (1970).College freshman attitudes toward cheating.The Personnel and GuidanceJournal, 48, 366 - 373.DOI: $10.1002 / j .2164-4918.1970 . t b 03332 . x$

[11]. Cole, S., \& Kiss, E. K. (2001).The delicate task of combating student cheating.Trusteeship, 9(1), 24-28.

[12]. Davis, S. F.,\&Ludvigson, H. W. (1995).Additional data on academic dishonesty and a proposal for remediation.Teaching of Psychology,22, 119-121.

[13]. Deikhoff, G. M., LaBeff, E. E., Clark, R. E., Williams, L. E., \&, V. J. (1996). College cheating: Ten years later. Research in Higher Education, 37(4), 487-502.

[14]. Denga, D. I., \&Denga, H. M. (1998).Educational malpractice and cultism in Nigeria: Analysis and confronting techniques. Calabar: Rapid Educational Publishers Ltd.

[15]. Egbezor, D. E. (1986).Job satisfaction among secondary school teachers in Rivers State. Unpublished M. Ed. Thesis, University of Port - Harcourt, Port - Harcourt.

[16]. Entwistle, N. J. (1976). Aberdeen Academic Motivation Inventory. In Johnson, O. G. (ed.). Test and measurement in childdevelopment: Handbook II (Vol. 1). San Francisco, California: Jossey - Bass publishers.

[17]. Feldman, R. S. (2000). Essentials of understanding psychology (4 ${ }^{\text {th }}$ ed.). Boston: McGraw-Hill Higher Education.

[18]. Gottfried, A. E. (1990). Academic intrinsic motivation in young elementary school children.Journal of Educational Psychology, $82(3), 525-538$.

[19]. Greene, A. S.,\& Saxe, L. (1992).Everybody (else) does it: Academic cheating. Paper presented at the Annual Meeting of the eastern Psychological Association. Boston, M. A.

[20]. Jacob, S., \&Lar, T. D. (2001). Forms and reasons of examination malpractice: Implications for national development. The NigerianAcademy of Education.Proceedings of the $16^{\text {th }}$ Annual Congress of the Nigerian Academy of Education held in the University of Jos, Jos, 12-16 November.

[21]. Johnson, D. W. (1979). Educational psychology. Englewood Cliffs, New Jersey: Prentice-Hall, Inc.

[22]. Jordan, A. E. (2001). College Student Cheating:The Role of Motivation, PerceivedNorms, Attitudes, and Knowledgeof Institutional Policy. Ethics \&Behavior, 11(3), 233-247.

[23]. Maduabum, M. A. (2001). Examination malpractice in Nigerian Education System: Perspectives and possibilities. The NigerianAcademy of Education. Proceedings of the $16^{\text {th }}$ Annual Congress of the Nigerian Academy of Education held in the University of Jos, Jos, 12-16 November.

[24]. Mangvwat, B. (2001). The incidence of examination malpractice and its impact on educational development in Nigeria.TheNigerian Academy of Education. Proceedings of the $16^{\text {th }}$ Annual Congress of the Nigerian Academy of Education held in the University of Jos, Jos, 12-16 November.

[25]. Newstead, S. E., Franklyn -Stokes, A., \&Armstead, P. (1996). Individual differences in student cheating.Journal of Educational Psychology, 88(2), $229-241$.

[26]. Ogbonna, B. B. O. (2001). Psychological dimensions in tackling the scourge of examination malpractice in Nigeria. The NigerianAcademy of Education. Proceedings of the $16^{\text {th }}$ Annual Congress of the Nigerian Academy of Education held in the University of Jos, Jos, 12-16 November. 
[27]. Okoro, C. C. (2001a). The impact of examination malpractice on the functionality of education in Nigeria.International Journal ofEducational Administration, Planning \& Research, 1(1), 105-114.

[28]. Okoro, C. C. (2001b). Relationship between achievement motivation and creativity in junior secondary students in Uyo metropolitan schools. Knowledge Review: A multidisciplinary journal, 4(1), 95 - 98.

[29]. Okorodudu, G. N. (2010). Peer pressure and socioeconomic status as predictors of students' attitude to examinationsmalpractice. Journal of Theoretical and Empirical Studies in Education, 2(1), 71-80.

[30]. Rabi, S. M., Patton, L. R.Fjortoft, N.,\&Zgarrick, D. P. (2006).Behind academic dishonesty in pharmacy school: Exploring characteristics, prevalence, attitudes and perceptions. American Journal of Pharmaceutical Education, $70(4), 73$.

[31]. Tukur, A. H., \& Musa, A. K. J. (2001). Examination malpractice among undergraduate students of University of Maiduguri: Conditions and forms. The Nigerian Academy of Education. Proceedings of the $16^{\text {th }}$ Annual Congress of the Nigerian Academy of Education held in the University of Jos, Jos, 12-16 November.

[32]. Udoh, Nsisong A. (2011). Remote Causes and Counseling Implications of Examination Malpractice in Nigeria.Student Pulse, 3 (10). Available at: $<$ http://www.studentpulse.com/a?id=585>

[33]. Udokang, S. J., \&Okoro, C. C. (2004).Principles of Educational Psychology. Uyo: Abaam Publishing Co.

[34]. Ugodulunwa, C. A. (2001). The attitude of students to cheating in examination.The Nigerian Academy of Education. Proceedings of the $16^{\text {th }}$ Annual Congress of the Nigerian Academy of Education held in the University of Jos, Jos, 12-16 November.

[35]. Whitley, B.E., Jr., Nelson, A. B.,\& Jones, C. J. (1999). Gender differences in cheating attitudes and classroom cheating behavior: A meta-analysis. Sex Roles: A Journal of Research, 657.

[36]. Zhou, H.,\&Lan, S. S. (2007). A comparative analysis on students' perceptions and attitudes towards academic dishonestybetween students in china and inthe United States.Proceedings of the Spring 2007 American Society for Engineering Education IllinoisIndiana Section Conference. Available http://ilin.asee.org/Conference2007program/Papers/Conference\%20Papers/Session\%205B/Zhou-Lan.pdf 